\section{Estimating Dryweights of Foodplants in Feces of Herbivores $^{1}$}

JAMES C. FREE, 2 RICHARD $M$. HANSEN, AND PHILLIP L. SIMS

Graduate Research Assistant, Professor of Range Biology, and Assistant Profes. sor of Range Science, Range Science Department, Colorado State University, Fort Collins.

\section{Highlight}

The dry weight composition of foodplants was estimated by a microscope technique for esophageal samples from steers, fecal samples of steers and fecal samples from sheep fed on the esophageal samples. Perennial species of foodplants forming more than $5 \%$ of the diets could be identified and quantified by the analysis of $\mathbf{1 0 0}$ microscope fields at 125 power magnification. The diagnostic features of fragile forbs were not as prominent in feces as they are in non-digested plants.

Knowing what foodplants an animal eats was once a worthwhile research objective but now it is essential to also study "when" and "how much" of each foodplant is consumed, the availability of the foodplant, and the digestibility of the foodplant. Progress in detcrmining some of these worthwhile objectives is being made using high power microscope and histology techniques in the analysis of feces of herbivores that masticate their foodplants into very fine particles. Several papers have been recently published on the potential for using various techniques for estimating the botanical and dry weight composition of herbivore diets from the microscopic examination

\footnotetext{
${ }^{1}$ Received August 9, 1969; accepted for publication October 29, 1969.

${ }^{2} \mathrm{Mr}$. Free is now a Range Conservationist with the U.S. Forest Service, White River National Forest, Meeker, Colorado.
}

of feces (Croker 1959; Dusi 1949; Hegg 1961; Hercus 1960; Kiley 1966; Stewart 1967; Storr 1961, 1963, 1964, 1968; Ward 1969; Williams 1969).

Recent studies have shown that only a few foodplants could not be found in the feces after they passed through a herbivore (Storr 1961, Williams 1969). Perhaps with preparation techniques similar to those developed by Williams (1969) it will be possible to recognize epidermal fragments from every foodplant that has passed through a herbivore. There is little or no digestion of epidermis that is encased in cutin and the relation between observed particles (surface area and frequency) and the dry weight of the foodplant can be determined by feeding a herbivore a known mixture of foodplants and by making a comparison between the weights of the known mixture and the measurements recordcd for the foodplant fragments found in the feces.

The purpose of this study was to determine if the dry weight composition of foodplants in the diets of herbivores could be predicted from the analysis of feces using the technique published by Sparks and Malechek (1968). They accurately estimated percent composition by dry weight for hand-compounded mixtures of plants that were likely to be found in the diets of herbivores. They overcame the problem of having a wide range of different sizes of particles by grinding the oven-dried foodplants through a $1 \mathrm{~mm}$ screen. After weighing and mixing the hand-compounded mixtures, the samples were washed over a 200 mesh screen to remove the smallest particles. The mixtures were sampled by recording the frequency of occurrence of each foodplant in 100 microscope fields under magnification, converting frequency to density, and calculating relative density. Sparks and Malechek (1968) found a $1: 1$ relationship between relative density and the dry weights of foodplants in the handcompounded mixtures $\left(\mathrm{r}^{2}=98 \%\right)$.

\section{Methods}

Esophageal samples were collected twice daily for three consecutive days from eight steers at the Eastern Colorado Range Station in mid-June, lateJuly, early-Septcmber and in mid-December, 1967. Grab-samples of cattle feces were taken once daily from each steer for five consecutive days in each study period. Cattle feces were not collected during the December sampling period because the steers were being fed a supplement that would have changed the fecal composition so it did not match the fistula sample. Columbia wethers were fed part of the forage collccted from the esophageal-fistulated steers. The sheep feces were then collected from metabolism cages during standard digestibility trials. The esophageal collections were washed in water but the fecal samples were not washed before all samples were dried in an oven between 60 and $70 \mathrm{C}$.

The esophageal samples and the fecal samples were ground in a Wiley mill through a $0.5 \mathrm{~mm}$ screen to reduce all plant fragments to a uniform size. Daily subsamples were composited to make up the sample used in the microscopic examination. Material used for microscope slides was washed over a $0.1 \mathrm{~mm}$ screen to insure mixing and to remove the small fragments. Five microscope slides were prepared for each sample according to procedure outlined by Sparks and Malechek (1968). The slides were oven dried at $60 \mathrm{C}$ for about 72 hours. The material used for making slides was treated with only the clearing and mounting solutions. The three kinds of samples were then examined by the microscope method (Sparks and Malechek 1968) for estimating percentage dry weights of foodplants.

Microscope reference slides were prepared from tissue of identified plants and plant parts collected on the study area. Foodplants in the fecal samples were identified by comparing the epidermal tissue with known food- 
plants on reference slides. Histological features such as size and shape of cpidcrmal trichomcs, presence or absence of trichomes, cell shapes, and crystals included in epidermal cells provided diagnostic characteristics for identification of forb species. Species of grasses were identified by the occurrence and position of such specialized epidermal cells as cork cells, silica cells, silica-suberose couples, and asperities. Undulating cell walls and size and shape of guard and subsidiary cells of the stomata were also valuable diagnostic features. Diagnostic characteristics for epidermal tissue varies with leaf surface, stem, and reproductive parts.

The dry weight composition of foodplants in each of the three samples was estimated by observing 20 systematically-located fields on each of the five slides with a compound binocular microscope at 125 power magnification. The presence of each species of plants in each field was recorded. Average frequency percentages were computed for all foodplants present in the samples. The relative density, calculated as the number of particles of a species expressed as a percentage of the total number of particles of all species (Curtis and McIntosh 1950) was determined for each species in the diet. Relative density was assumed to be equal to the dry weight composition of each food item in the diet (Sparks and Malechek 1968).

The error in predicting relative percentage of dry weight will decrease as sample numbers and numbers of microscope fields examined increases. Sparks and Malechek (1968) used 15 mixtures and examined 100 fields/ mixture to obtain an $\mathrm{r}^{2}$ value of $98 \%$ when they compared their estimates with the actual dry weights. We observed that the calculated mean percentages of dry weight for common food items for 60 and 100 microscope fields in our samples usually changed less than five percent. We assume that the estimates of dry weight in this paper are most accurate for the fistula-collected samples.

\section{Results and Discussion}

There were small differences in the estimated mean percent dry weight of the species of grasses found in the esophageal samples from steers, the fecal samples from steers and the fecal samples obtaincd from sheep that had
Table 1. Mean relative density (\%) of items in esophageal samples of steers, fecal samples of steers and fecal samples from sheep fed on the esophageal samples.

\begin{tabular}{|c|c|c|c|c|c|c|c|c|c|c|c|}
\hline \multirow[b]{2}{*}{ Species } & \multicolumn{3}{|c|}{ Mid-June } & \multicolumn{3}{|c|}{ Late-July } & \multicolumn{3}{|c|}{ Early-Sept. } & \multicolumn{2}{|c|}{ Winter } \\
\hline & $\mathrm{Fi}^{1}$ & $\mathrm{Fe}^{2}$ & $\mathrm{Fe}^{3}$ & $\overline{\mathrm{Fi}^{1}}$ & $\mathrm{Fe}^{2}$ & $\mathrm{Fe}^{3}$ & $\overline{\mathbf{F i}^{1}}$ & $\mathrm{Fe}^{2}$ & $\overline{\mathrm{Fe}^{3}}$ & $\overline{\mathrm{Fi}^{1}}$ & $\mathrm{Fe}^{3}$ \\
\hline \multicolumn{12}{|l|}{ Grasses and grasslikes } \\
\hline Bouteloua gracilis & 32 & 40 & 42 & 24 & 31 & 25 & 42 & 50 & 41 & 28 & 20 \\
\hline Calamovilfa longifolia & 19 & 19 & 23 & 38 & 33 & 42 & 12 & 10 & 18 & 3 & 4 \\
\hline Stipa comata & 15 & 12 & 11 & 4 & 9 & 5 & 15 & 10 & 12 & 54 & 55 \\
\hline Agropyron smithii & 15 & 14 & 15 & 10 & 10 & 11 & 20 & 9 & 21 & 14 & 17 \\
\hline Andropogon hallii & 3 & 3 & 2 & 12 & 2 & 3 & 2 & 2 & 1 & & \\
\hline Sporobolus cryptandrus & 1 & 1 & & 2 & 2 & 10 & 3 & 10 & 4 & 1 & 3 \\
\hline Carex heliophila & 1 & 2 & 3 & $<1$ & 2 & 2 & 2 & 2 & & & \\
\hline Other grasses & $<1$ & & & $<1$ & & & $<1$ & 1 & & 1 & 1 \\
\hline Total & 86 & 91 & 96 & 90 & 89 & 98 & 96 & 94 & 97 & 99 & 98 \\
\hline
\end{tabular}

Forbs

\begin{tabular}{|c|c|c|c|c|c|c|c|c|c|c|c|}
\hline Tradescantia occidentalis & 4 & 2 & & 1 & 1 & & & 1 & & & \\
\hline Artemisia ludoviciana & 2 & & & 2 & & & 1 & & & & \\
\hline Chenopodium album & 2 & & & 1 & & & & & & & \\
\hline Cirsium undulatum & $<1$ & & & 1 & & & 1 & & & $<1$ & \\
\hline Sphaeralcea coccinea & $<1$ & 2 & & 1 & 4 & 1 & 1 & 1 & & & \\
\hline Ambrosia psilostachya & 1 & & & $<1$ & & & $<1$ & & & & \\
\hline Lepidium densiflorum & 1 & & & $<1$ & 1 & & & & & & \\
\hline Kochia scoparia & $<1$ & 1 & & $<1$ & 2 & & & & & & \\
\hline Ipomoea leptophylla & $<1$ & & & $<\mathrm{l}$ & & & & & & & \\
\hline Conyza canadensis & & & & $<1$ & & & & & & & \\
\hline Helianthus petiolaris & & & & $<1$ & & & & & & & \\
\hline Other forbs & 2 & 4 & 4 & 3 & 3 & 1 & 1 & 4 & 3 & 1 & 2 \\
\hline Total & 14 & 9 & 4 & 10 & 11 & 2 & 4 & 6 & 3 & 1 & 2 \\
\hline
\end{tabular}

${ }^{2} \mathrm{Fi}=$ fistula sample from steers.

${ }^{3} \mathrm{Fe}=$ fecal sample (cattle).

${ }^{3} \mathrm{Fe}=$ fecal sample (sheep).

consumed the same esophageal-collected samples (Table 1). The similarity of the estimated dry weights of these grasses in the three samples is well within the errors that occur in sampling. Forbs and annual plants made up only a small portion of the samples during all four collections. The epidermal tissue of forbs was not as easily found in the cattle and sheep feces as it was in the fistula samples. The mean size of epidermal fragments in the feces was smaller than that of the ground fistula sample and most fragments in the ground feces of sheep were smaller sized than those in the ground feces of cattle. The epidermal fragments and diagnostic trichomes of some foodplants were often subdivided in the feces of sheep to such an extent that only an extremely careful, welltrained technician could recognize their presence.

Small, hard lumps of epidermal tissue were found when making slides of the sheep feces. These could not be easily dispersed on the microscope slide. These lumps are from the outside surface of the sheep pellets where mucus forms a hard layer with the outer particles of feces. Ignoring these lumps or taking them out as we have done may affect the estimated dry weight of certain species. If these particles are made up of the epidermis of the foodplants which were generally not found in the samples of feces, it might be possible to increase the accuracy of estimates if improved mounting and staining techniques are used. When fresh sheep, deer and antelope pellets are washed in a dilute lye solution before drying, these hard lumps are not evident in slides made from the subsequently ground samples. Storr (1961) and Williams (1968) have both used techniques not tried in our research.

The major components in the diets of herbivores should be identified to species. Generally this is not difficult. Small differences in intra-specific vari- 
ation of epidermal characters between congeneric species occasionally requires "lumping" more than one species in a diet category. Identification will often depend upon aboveground plant biomass records from the pasture or area where the fecal sample is taken. For species of big game that feed one place and excrete in another place, it is important to have aboveground plant biomass records from the places where the animals do their eating.

The identification of forbs in sheep feces on rangelands dominated by forbs poses an important problem. However, it appears that perennial foodplants forming more than $5 \%$ of the diet can be identified and quantified by the analysis of 100 fields of a microscope at 125 power magnification using known techniques for analyzing feces of herbivores.

\section{Literature Cited}

Croker, Barbara H. 1959. A method of estimating the botanical composition of the diet of sheep. New Zeal. J. Agri. Res. 2:72-85.

Dusi, J. L. 1949. Methods for the determination of food habits by plant microtechniques and histology and their application to cottontail rabbit food habits. J. Wildl. Manage. 13:295-298.

HegG, Oтto. 1961. Analysis of biggame droppings to determine their dietary composition in the Swiss National Park. Revue Suisse de Zoologie 68:156-165. Translated by J. J. Stransky. Southern Forest Exper. Station, U.S. Forest Serv., U.S. Dep. Agr., 9 p.

Hercus, Barbara H. 1960. Plant cuticle as an aid to determining the diet of grazing animals. VIII International Grassland Cong. Proc.:443447.

Kileey, MakThe. 1966. A preliminary investigation into the feeding habits of the waterbuck by faecal analysis. East African Wildl. J. 4:153-157. (Univ. Sussex, Falmer, Sussex, England).

Sparks, D. R., and J. C. Malechek. 1967. Estimating percentage dry weight in diets. J. Range Manage. 21:203-208.

Stewart, D. R. M. 1967. Analysis of plant epidermis in faeces: a tech- nique for studying the food preferences of grazing herbivores. J. Applied Ecol. 4:83-111.

STORR, G. M. 1961. Microscopic analysis of faeces, a technique for ascertaining the diet of herbivorous mammals. Austral. J. Biol. Sci. 14: 157-164.

STORR, G. M. 1963. Estimation of dry-matter intake in wild herbivores. Nature 197:307-308.

STORR, G. M. 1964. Studies on marsupial nutrition. Australian J. Biol. Sci. 47:469-481.

Stork, G. M. 1968. Diet of kangaroos (Megaleia rufa and Macropus robustus) and Merino sheep near Port Hedland, Western Australia. The Royal Soc. Western Australia $51: 25-32$.

Ward, A. L. 1969. Stomach content and fecal analysis: Methods of forage identification. Rocky Mountain Forest and Range Experiment Station, Fort Collins, Colorado 80521, 54 p. (In process)

Williams, O. B. 1969 . An improved technique for identification of plant fragments in herbivore feccs. J. Range Manage. 22:51-52. 